\title{
Reframing manufacturing research: place, production, risk and theory
}

\author{
John R. Bryson, Chloe Billing, William Graves and \\ Godfrey Yeung
}

Manufacturing matters and will always matter. The COVID-19 pandemic is associated with the rapid acceleration of innovation and with enhanced digitalization of production systems and consumer behaviour (Bryson et al., 2020). The shift towards online shopping and online living that was associated with the COVID-19 pandemic produced alterations in consumer behaviour and some of these may be permanent. Companies had to cope with supply chain disruptions, alterations in working practices with the imposition of social distancing in the workplace, combined with alterations and disruptions in consumer demand. Some of these alterations in working practices will become permanent as companies alter the balance between working from home and working in company offices. Thus, in March 2021, BP announced that it would be introducing a new hybrid work model for office-based employees who would be expected to work 40 per cent of the time at home (BBC, 2021). The pandemic has highlighted the complex interrelationships that exist between the worlds of production and consumption and the ways in which these are mediated by supply chain management and logistics. This highlights that any attempt to theorize manufacturing, or production, must be placed within a wider framework that includes consumption and logistics.

Manufacturing is about transforming raw materials to create both use and exchange values that are released at the moment of consumption. This requires raw materials, components and packaging to be delivered to manufacturing plants, and for completed products to be provided to consumers at a specified place. This involves the design of operational systems within and between manufacturing plants that are supported by logistics. Data and data analytics play a critical role in both the management of operational systems and logistics. There are multiple moments of value creation. These include values related to the effective management of a company's operations and 
engagement with logistics. This is about efficiency combined with location. It is also about the ability of any one company to negotiate better outcomes compared to competitors. These better outcomes include configuring a supply chain that provides access to higher-quality and/or cheaper inputs as well as configurating more agile and cost-effective logistics. This includes companies configuring supply chains designed to balance cost control and price with the production of eco-friendly products (Peattie and Crane, 2005). It also includes non-price-based values that may play an important role in consumer decisions. Products may be sold on price based on production systems that focus on stripping out costs to maintain margins. For these products, there is a direct interrelationship between the sales price and production costs. Alternatively, products are differentiated in the marketplace based on non-price-based values including corporate social responsibility, environmentally friendly products, and companies which pay living wages and which try to ensure that their supply chains include no examples of modern-day slavery and labour exploitation. Products may also be embedded in value chains that are focused on the production and sale of additional value by the provision of product-related services. This includes finance packages for purchase and insurance, training, servicing and recycling.

There are many reasons why it is important to research manufacturing. First, everyday living across the world is dependent on a vast array of manufactured products. Many of these products are hidden from everyday citizens, for example, sewage and water pumps, electricity generators, and the optical fibre trunklines and satellites that are the internet's backbone.

Second, every consumption decision directly or indirectly engages with manufacturing. Every service is supported by manufacturing products and every manufactured product is enmeshed in services (Bryson et al., 2020). These consumption decisions link the consumer with different forms of labour practice, and this includes slave labour and labour exploitation. Every consumer decision creates and sustains employment but also contributes to environmental pollution. Identifying and understanding some of the negative impacts of manufacturing processes and of the configuration of specific global value chains (GVCs) or global production networks (GPNs) should be central to all manufacturing research.

Third, human civilization faces major risks or societal challenges. Many of these are directly or indirectly linked to production systems. Carbon-intensive production systems and carbon-intensive lifestyles are the primary drivers behind anthropogenic climate change. The ongoing intensification of globalization, including the fragmentation of value chains, has produced a socio-economic 
system that is overtly reliant on the physical movement of raw materials, products, people, money and expertise between places. The world economy has become transformed into a complex set of flows. This comes with many benefits, but there are risks. On the one hand, COVID-19 has highlighted that with enhanced global connectivity, disease anywhere is now potentially disease everywhere. On the other hand, there is a tension between the design of GPNs to enhance profitability based on managing out costs and the configuration of carbon-intensive GPNs (IMO, 2020). A primary research challenge is the decarbonization of production systems and of supply chains.

Fourth, the complexity of production systems requires the development of new methodologies and theories with a focus on advancing understanding to inform policy in order to reduce the negative societal impacts of manufacturing and to contribute to more sustainable approaches to the configuration of GPNs and manufacturing production processes.

This chapter engages with some of the core building blocks that should underpin any research on manufacturing. The aim is to encourage a research dialogue that will reframe existing approaches to manufacturing research, to facilitate the emergence of new research agendas. The chapter is divided into eight sections. The second section explores the tensions between research on manufacturing that is positioned around firms, and understanding firm behaviour, compared with a focus on products. In the third section, attention is given to exploring the variegated nature of the manufacturing sector. The fourth section builds on the concept of variegated manufacturing by exploring the diversity of approaches to monetarization developed by manufacturing companies, including financialization. Scale, and the challenge of applying a multi-scalar approach to manufacturing, is explored in the fifth section. The sixth section focuses on exploring manufacturing paradoxes and the emergence of new forms of risk. In the seventh section, a discussion of manufacturing research and developing a socially responsibility research agenda is explored. The eighth and final section provides an overview of this book.

\section{Firms versus products}

The history of research into economic activities is one in which different scholars and disciplines study the same object, but there is no agreement regarding the definition of core terms or the application of theories, concepts or methods. Different scholars respond to different societal challenges, paradoxes or enigmas by defining the object of study in very different ways. This 
is a major challenge for exploring manufacturing research and for developing new research agendas.

The continued development of disciplinary silos ensures that transdisciplinary research is challenging and often impossible. Yet, the societal challenges and enigmas that need to be addressed cut across disciplinary boundaries as well as policy and stakeholder silos. There are perhaps four critical challenges that need to be addressed: climate change, inclusion including reductions in inequality and poverty, decent work for all, and developing global solutions for global problems including international trade, biosecurity and the climate crisis. All these critical challenges require transdisciplinary research.

Defining and developing agreement on the object of study is critical. For manufacturing research this is especially challenging. Is the object of research the firm, the product, or the process, or all of these? Is the focus on firms and processes in place and across space? Is the focus on product, process and/or employee? Is the focus on operations and/or strategy? Is the focus on people and/or flows of money, including financialization? Is manufacturing severed from other production processes, for example, finance, logistics and services including retailing? For many academics, the starting point is the firm (Dicken and Thrift, 1992; Taylor and Asheim, 2001; Goldstein and Newell, 2019). Some would argue that 'theorizing the firm in economic geography is fundamental to understand how local economies and communities function and evolve in globalising economic environments' (Taylor, 2006: 3). It is hard to disagree with this statement. Nevertheless, research projects that prioritize firms as the object of study tend to focus on understanding the configuration of global value chains or global production networks, highlighting processes connected to efficiency and competitiveness. The firm rather than the service product or good perhaps appears to be the object of study, but the paradox is that the focus of much of this research is not on firms, but on goods/services or on production processes configured to produce a specified product. Most firms manufacture many different varieties of product and each product may have a specially configured production system. Thus, a core research challenge is to develop more holistic approaches to understanding the multiple ways in which value is produced by firms and their related production and service processes.

In some accounts, the firm is taken to be the 'phenotype' or the smallest unit of analysis (Maskell, 2001; Taylor and Asheim, 2001). But for more complex firms, the phenotype might not be the firm, but some subunit, for example, a division or a subsidiary. Too many academics perhaps confuse research that is undertaken at the level of a subsidiary, division or plant with the complete firm. There are many challenges in defining the object of study as the firm. The 
primary challenge is the definition that is deployed. In some accounts, the firm is taken for granted and no attempt is made to define the firm. Nevertheless, every academic, policymaker and practitioner will have a slightly different definition of firms. Different approaches to defining firms will include firms as the loci of a set of timeless processes that include:

- Profit maximization.

- Decision-making under uncertainty.

- Rules, rituals, routines, habits and conventions.

- Learning, knowledge creation and transfer, and innovation.

- Employee recruitment, training and performance management.

- Corporate activity systems: operations management, sales and marketing, accounts, human resource management, procurement, supply chain management, corporate governance, and so on.

- Improvization under uncertainty.

- Bounded rationality and information asymmetry.

- Path dependency linked to sunk costs.

- Risk versus reward.

All these timeless processes are positioned around definitions of firms which highlight that they operate as mechanisms for coordinating, motivating and assessing individuals in the context of some form of value creation process. Motivation is important in this context, as a primary role played by firms is to 'direct and align perception, understanding, and evaluation by the people connected with it' (Nooteboom, 2000: 71).

People play a central role in firms. This includes exploitation of others, including being directly or indirectly complicit in modern-day slavery, or the severe exploitation of other people for commercial gain, with sexual abuse and sexual harassment against women, and all types of discrimination and exclusionary behaviour. In 2016, the International Labour Organization (ILO) estimated that 40 million people were victims of modern slavery, with 25 million in forced labour; there were 5.9 adult victims of modern slavery for every 1000 adults in the world, and 4.4 child victims for every 1000 children (ILO, 2017: 5). Too many GPNs are configured around severe labour exploitation combined with environmental pollution.

Within firms, there is a small group of people involved in strategic decision-making, a much larger group involved in the management of everyday operations, and an even larger group that is removed from having any significant input to organizational decisions. Organizational decision-making reflects trade-offs that are negotiated between senior managers. This is a polit- 
ical process that is also shaped by external influences including shareholders, competitors, politicians and the media, including social media. Very little research has been undertaken that has focused on understanding the negotiation of trade-offs in the context of manufacturing research. This is an important research gap, as the configuration of a GPN is one outcome of these types of negotiation processes. This is a complex process, as negotiations result in decisions that are then layered on top of decisions that have been made in the past. This process of layering produces symbiotic and perverse or unexpected outcomes.

An alternative approach to defining firms is based on identifying key characteristics. These include the firm as a:

- controller and coordinator of assets;

- negotiator and enforcer of contracts;

- set of relationships between people and other organizations;

- collective of individuals who have come together to achieve some common purpose;

- legal entity that can negotiate and agree written and unwritten contracts for which it is legally accountable;

- tax entity and tax collector;

- locus where societal needs are aligned with production processes to create use and exchange values.

Different scholars will emphasize some of these characteristics over others. There are perhaps surprising omissions in the literature. Very few papers explore how contracts are negotiated and enforced as well as the contribution contracts make to procurement processes, the configuration of GPNs and to path dependency (Mulhall and Bryson, 2013, 2014). There has been a significant emphasis placed on trust in interorganizational relationships, but these relationships are underpinned by written and unwritten contracts. These contracts might be underpinned by trust or the reputational damage that would result from any threat of contract enforcement (Bryson and Taylor, 2010; Taylor and Bryson, 2006).

Treating the firm as the object of study then highlights three critical activities. First, all firms are goal-directed, but not all firms are driven by a sole focus on profit maximization. Different firms have different motivations and very disparate drivers, including a triple bottom line approach or market maximization. Goal-direction does not mean that decisions made by a firm will be rational and will not result in perverse consequences including organizational failure. With very few exceptions, all firms eventually fail, and failure is the 
result of some balance between exogenous and endogenous factors. For some firms, failure is due to poor decision-making. Understanding failure is a critical research area and is one that is too often neglected. Second, a firm is a legal entity, and this highlights that a core function is in maintaining and clearly demarcating the boundary between a firm and other firms. The legal boundary is clearly defined as the governance structure that has the right to agree contracts and against which legal proceedings can be instituted. In operational terms, the boundary of a firm is much more complex, as many firms can only operate through a multiple array of interlocking arrangements with other organizations, but all such arrangements are regulated by contract law. Third, a firm is the locus within which a set of activity systems have been established that include accessing information, knowledge creation, product design, sourcing and procuring raw materials, recruitment and training employees, and creating service products or goods that can be monetarized in some way.

A GPN is not a firm, but a collection of firms. Each firm will be goal-directed, but there will be very many different types of goals. For some firms, involvement in a particular GPN will be business-critical, and for other firms it will represent a minor part of their business activities. There is an interesting tension in the GVC and GPN literatures between firms, networks and products. Much of the research is focused on products and the ways in which their GPNs are configured by a lead firm. But these lead firms will be configuring many different forms of good/product GPNs; the interactions between different forms of configuration within the same firm are perhaps as important as the configuration of any specific good/product GPN. This includes different forms of joint ventures and strategic partnerships with various partners and with different modes of governance. This is an important research gap that requires further attention.

Decisions regarding the object of study illuminate some processes and place other processes in darkness. There are two points to consider here. On the one hand, it is important not to isolate one aspect of a firm from the firm's wider context. Thus, focusing on one product, activity system or GVC or GPN is to separate a process from a much more complex set of processes and decisions. On the other hand, displacing the firm as the object of study with a good/service product, or some combination, focuses the analysis on processes, decisions and outcomes that are required to close the gap between the demand and supply of some good or service product. The type of good/service product raises interesting research questions that should be central to the manufacturing research agenda. These include alternative ways of designing a product to increase fabrication efficiency, to reduce good/product-related environmental pollution, including decarbonizing operational processes, or 
to increase good/product societal inclusion. Too much emphasis has been placed on understanding offshoring and reshoring, and capital substitution for labour (Urry, 2014; Peck, 2019), and too little research emphasis has been placed on the implications of the redesign of operational procedures combined with good/product redesign (Vanchan et al., 2018). This is a call for a good/ product-informed, or good/product-centric, understanding of both firms and GVCs and GPNs (Bryson and Rusten, 2011). Nevertheless, this is only one entry point to understanding manufacturing that must also be positioned within an analysis of labour exploitation, environmental impacts and the variegated nature of manufacturing.

\section{Variegated manufacturing}

The manufacturing sector is extremely heterogeneous. These differences range from companies involved in the production of comparatively simple products that involve very few inputs, to goods that contain over 1 million components. Every physical good is the outcome of a distinctive production process that involves the configuration of machines and production tasks. These tasks might be completely mechanized with employees overseeing the process, focusing on supervision and maintenance. All tasks may be located at the same site, or the complete good might be the outcome of a production process that has been fragmented via the application of a spatial division of labour leading to some form of GVC or GPN. The manufacture of a good might be extremely labour-intensive with limited application of technological solutions to the performance of tasks. The heterogeneity of manufacturing takes three forms: by type of firm, the configuration of the production processes and good/service product combinations.

The degree of heterogeneity implies that manufacturing research is an exercise in identifying and understanding the variegated nature of manufacturing or production systems. All theories developed to explain some aspect of manufacturing must be able to engage with the variegated nature of manufacturing. This includes theory that can be applied to complex, highly fragmented production systems, or GPNs, and manufacturing processes which are predominantly localized and which are only indirectly linked to GVCs or GPNs. It is important to consider the three processes that sit behind manufacturing's variegation.

First, there are an infinite variety of firms involved in manufacturing goods and in configuring manufacturing processes. These include international or 
global businesses. An analysis of the largest manufacturing companies by revenue highlights the continued importance of automotive companies and the dominance of American, Japanese and German companies in the global rankings of the largest manufacturing companies (Table 1.1). Nevertheless, these extremely large manufacturing companies are unusual, with most companies involved in manufacturing being small and medium-sized enterprises (SMEs) (Gallemore et al., 2019; Wang, 2019). The national context is important here. A comparative analysis of firm size and employment growth between Japanese and United Kingdom (UK) manufacturing firms between 1972 and 1991 identified significant differences between these countries; over this period in the UK both the total stock of small manufacturing firms and employment increased, but there was no increase in employment amongst Japanese firms (Doi and Cowling, 1998). There is no question that manufacturing firms of different sizes and ages play different roles in terms of employment, growth, innovative activities and wider socio-economic impacts (Ge et al., 2020). There is an important research agenda here that should focus on the relationships between firm size, place, production network, and wider socio-economic contributions.

The variegated nature of manufacturing firms includes transnational to small single-site family businesses, branch plants to complete corporations, joint ventures and subsidiaries, franchisees to subcontractors, sole proprietorships to listed companies, for-profit and not-for-profit companies, and companies held in various forms of employee ownership scheme (Fernández-Esquinas et al., 2017). The last of these may be 100 per cent employee-owned. Employee ownership alters the relationship between employee and employer by blending capitalism with communitarianism (Sauser, 2009). Some of these are large firms that make important products (Table 1.2). These firms challenge existing practices and represent an important research area, but one that has been neglected. Employee-owned firms may be juxtaposed against sweatshops, or factories and workshops with employees on very low wages, working long hours and often in unsafe conditions. Many GPNs have hidden within them these types of manufacturing firms that are based on labour exploitation. The variegated nature of manufacturing firms also includes state-owned enterprises (SOEs) that may operate in very different ways to other types of firms. A SOE may operate in the same way as other companies, but there may also be important differences that need to be identified and acknowledged. There is a further complication in that the form of governance that exists in the host state will impact on the operation of a SOE. A SOE may be at arm's length from the government owner or may be a corporate vehicle intended to advance some political objective. 
Table 1.1 Largest manufacturing companies by revenue, 2020

\begin{tabular}{|c|c|c|c|c|c|}
\hline Rank & Company & Industry & $\begin{array}{l}\text { Revenue } \\
\text { (US\$m) }\end{array}$ & Employees & Headquarters \\
\hline 1 & $\begin{array}{l}\text { Volkswagen } \\
\text { Group }\end{array}$ & Automotive & 282760 & 671205 & Germany \\
\hline 2 & Toyota Group & $\begin{array}{l}\text { Engineering, } \\
\text { various }\end{array}$ & 275288 & 359542 & Japan \\
\hline 3 & $\begin{array}{l}\text { Samsung } \\
\text { Electronics }\end{array}$ & $\begin{array}{l}\text { Electronics, } \\
\text { various }\end{array}$ & 197705 & 287439 & South Korea \\
\hline 4 & Daimler & Automotive & 193346 & 298655 & Germany \\
\hline 5 & $\begin{array}{l}\text { Hon Hai } \\
\text { Precision } \\
\text { Industry } \\
\text { (Foxconn) }\end{array}$ & Electronics & 172869 & 757404 & Taiwan \\
\hline 6 & Ford & Automotive & 155900 & 190000 & United States \\
\hline 7 & Honda & Automotive & 137332 & 218674 & Japan \\
\hline 8 & $\begin{array}{l}\text { General } \\
\text { Motors }\end{array}$ & Automotive & 137237 & 164000 & United States \\
\hline 9 & Mitsubishi & $\begin{array}{l}\text { Engineering, } \\
\text { various }\end{array}$ & 135940 & 86098 & Japan \\
\hline 10 & Huawei & $\begin{array}{l}\text { Tele- } \\
\text { communications } \\
\text { equipment, } \\
\text { Electronics }\end{array}$ & 124316 & 194000 & China \\
\hline 11 & $\begin{array}{l}\text { China } \\
\text { Railway and } \\
\text { Engineering } \\
\text { Group }\end{array}$ & Engineering & 123324 & 302394 & China \\
\hline 12 & SAIC Motor & Automotive & 122071 & 151785 & China \\
\hline
\end{tabular}

Source: Adapted from Fortune (2020).

Second, similar manufactured goods can be produced by the application of a different configuration of machines, labour inputs and configurations of supply chains. These differences are ignored in much of the literature, but they will become increasingly critical. We need to know much more about alternative approaches to manufacturing similar products, with a focus on reducing environmental impacts and enhancing recyclability and sustainability. These differences include goods that have been redesigned in response to the monomaterials challenge. The very near future will be associated with a radical shift, from products that are designed to incorporate a variety of raw 
Table 1.2 Majority employee-owned American manufacturing companies, 2020

\begin{tabular}{|c|c|c|c|c|}
\hline Rank & Company & Business & $\begin{array}{l}\text { Date of } \\
\text { establishment }\end{array}$ & Employees \\
\hline 1 & Amsted Industries & $\begin{array}{l}\text { Industrial } \\
\text { components }\end{array}$ & 1986 & 18000 \\
\hline 2 & $\begin{array}{l}\text { W.L. Gore \& } \\
\text { Associates }\end{array}$ & Manufacturing & 1974 & 10800 \\
\hline 3 & $\begin{array}{l}\text { Challenge } \\
\text { Manufacturing } \\
\text { Company }\end{array}$ & $\begin{array}{l}\text { Automotive } \\
\text { manufacturing }\end{array}$ & 1987 & 3000 \\
\hline 4 & EVAPCO Inc. & Manufacturing & 1984 & 3000 \\
\hline 5 & $\begin{array}{l}\text { Krueger } \\
\text { International, Inc. }\end{array}$ & $\begin{array}{l}\text { Furniture } \\
\text { Manufacturing }\end{array}$ & 1991 & 3000 \\
\hline 6 & S\&C Electric & $\begin{array}{l}\text { Electrical } \\
\text { equipment }\end{array}$ & 1989 & 2600 \\
\hline 7 & $\begin{array}{l}\text { Jasper Engines \& } \\
\text { Transmissions }\end{array}$ & $\begin{array}{l}\text { Engine and } \\
\text { transmission } \\
\text { remanufacturing }\end{array}$ & 2010 & 2400 \\
\hline 8 & $\begin{array}{l}\text { Bradford White } \\
\text { Water Heaters }\end{array}$ & Water heaters & 1992 & 2300 \\
\hline 9 & $\begin{array}{l}\text { Columbia Forest } \\
\text { Products }\end{array}$ & Plywood & 1977 & 2100 \\
\hline 10 & Airborn Inc & $\begin{array}{l}\text { Electronic } \\
\text { connectors }\end{array}$ & 1996 & 1500 \\
\hline
\end{tabular}

Source: Adapted from NCEO (2020).

materials, to monomaterial products. Monomaterial products facilitate 100 per cent material recycling. Monomaterial products will emerge across all sectors, with perhaps one of the lead sectors being packaging (Nguyen et al., 2020). By 2030, all plastic packaging used within the European Union (EU) must be recyclable and reusable (Boz et al., 2020). This requires companies within all GVCs and GPNs to redesign goods and related packaging (Skoda, 2019). A good example is the environmentally friendly monomaterial baseball cap made by Atlantis. This includes a QR (quick response) code that when scanned provides access to the Atlantic tracking system, which provides information about the product's supply chain journey from the place of manufacture to the point of consumption; the QR code includes details of the production location, inland transportation, departure and arrival ports and vessel's name. These baseball caps are made from 100 per cent recycled fabric as well as including near-field 
communication (NFC) technology which enables information embedded in the cap to be shared with devices equipped with an NFC chip.

A primary corporate and academic challenge relates to the decarbonization of manufacturing processes and related supply chains (Dangelico and Pujari, 2010). This involves both product and production process redesign, but also identifying and removing processes and tasks that are carbon-intensive. This includes both the decarbonization of operations and logistics combined with waste reduction and recycling. In other words, this is about the development of zero-waste and zero-emissions manufacturing production processes and related products. Manufactured goods will increasingly be differentiated not on price but on environmental credentials. In any case, the production of some goods will no longer be permitted on environmental grounds. Clothing supply chains will increasingly engage with the food production system with innovations in the conversion of food by-products into textiles. Thus, Piñatex has emerged as a fruit-based vegan leather made from waste pineapple leaf fibres that cannot be eaten, and 'Orange Fiber' is created from waste orange peel discarded during the manufacture of orange juice. An alternative is recycling waste plastic into new fabric. Olas leggings, for example, are designed and made in England from Italian fabric from 78 per cent recycled polyester and 22 per cent Lycra. The laundry advice for this product is to hand wash using a green detergent and to deposit the used water in the soil to avoid microfibres polluting oceans. This highlights an important paradox: eco-friendly products also create environmental pollution.

The ecological aspects of manufacturing will become an extremely important new research agenda. This will include decarbonization linked to direct and indirect energy embedded in products, but also recycling and reuse. A good example are the products made for the Girlfriend Collective. This company's packaging is 100 per cent recycled and recyclable. The firm's leggings are made from 79 per cent recycled polyester, with a pair of leggings made from 25 recycled post-consumer bottles, and a bra from 11 bottles. Their range of LITE leggings are made from 83 per cent recycled fishing net, and other waste, and the company's T-shirts are made from the waste left by the cotton industry, with the yarn made in a zero-waste, zero-emissions facility in Japan. The Girlfriend Collective has also introduced the 'recycle, reuse and reGirlfriend' scheme. When a customer is finished with an old Girlfriend product then they can purchase a shipping label from the company's website. On receipt, the polyester is separated from the spandex and new fibres formed to make new Girlfriend pieces. The consumer receives a $\$ 15$ store credit towards the purchase of a new item of clothing. The company's fabrics are designed to enhance recyclability. 
Third, manufacturing has changed and continues to change. This includes the blurring of the boundaries between manufactured goods and service products (Daniels and Bryson, 2002). It has become increasingly difficult to isolate the production and consumption of goods from service products. There are product hybrids that combine both physical goods and services, for example, smartphones and laptops; and also goods that have been converted into services (Bryson et al., 2020). In the latter case, consumers no longer purchase the good, but purchase service inputs. Good examples are companies that provide mobility services rather than selling vehicles, or firms that provide pumping hours rather than selling industrial pumps. The conversion of a good into a service comes with many advantages. Selling a good includes one profit realization moment, whilst converting a good into a service provides the producer with a continual stream of profit realization moments. There are also sustainability advantages as the producer is completely responsible for product maintenance and for recycling. A key challenge for research on manufacturing is to develop a holistic approach that explores companies producing and selling similar goods, but using different channels to market and different configurations of production network and approaches to monetarization. This type of holistic approach would require more research that placed the analysis of a GPN within the context of the complete firm. Each channel will have very different characteristics including different forms of competitiveness, and each will have a different environmental footprint.

\section{Monetarization, financialization and manufacturing}

At the centre of all manufacturing processes is a monetarization process that is focused on converting something into money. Monetization requires a much broader critical discussion regarding value (Bryson and Vanchan, 2020). An important manufacturing research agenda involves developing a critical debate on value: for whom, for what, and from what. Too often, value is assumed or taken for granted. Value includes monetized and non-monetized values and different blends of these forms of value (Bryson et al., 2018). Value may include economic prosperity, inclusive economic prosperity, environmental protection and social justice.

Too often it is assumed that companies adopt similar approaches to the monetization of value. Thus, a research agenda may only focus on monetized value based on the assumption that the primary role of a firm involves minimizing costs and maximizing revenues and profitability. Anything that is assumed within a social science research agenda must be challenged. Different firms 
will operate to very different margins, and this reflects different governance structures including ownership, but also decisions related to product differentiation. Some products compete solely on price and other products compete on non-price-based characteristics (Bryson and Ronayne, 2014). For some products there is a direct relationship between production cost and the final sales price, and for similar products there may be a very different relationship between costs versus sales price. Further research is required into the relationship between monetarization and different approaches to configuring goods/ service product combinations and their production networks. Monetization is a very complex issue as contributions to product profitability may emerge across a GPN. This is an under-researched area. There are two important points to consider.

First, is the analysis of monetarization and manufacturing made at the level of the firm or product? A product line may be a loss leader, or profitability may be hidden through the application of various forms of financial engineering including transfer pricing. For a product, profit may emerge via the application of a spatial division of labour that underpins the configuration of a GPN, and this might include labour exploitation. Contributions to product profitability may rest on effective negotiation of procurement contracts in which order size might be used to transfer margins from suppliers to the procurer. Effective negotiation might be good business, but it might also reflect socially irresponsible business practices. Monetarization might not be directly related to the manufacture of a product. A product may be manufactured to a low or break-even margin, as the primary monetarization moment might be focused on the sale of consumables. A classic example of a revenue-based monetarization model is found in the 'razor-razor blade' model. This operates by 'pricing razors, or computer printers, inexpensively but placing higher margins on consumables - razor blades or printing ink' (Bryson et al., 2020: 51). Monetarization may also include data monetarization in which information is acquired from consumers and then repackaged and sold as data-related products. This also includes the monetarization of websites through the development of revenue-based models. Another form of product-related service monetarization is found in the sale of products that are supported by the provision of finance packages including appliance insurance policies and extended warranties. Automotive companies prefer not to sell vehicles outright, but instead encourage consumers to take out finance packages.

At the corporate rather than the product level, monetarization includes financialization (Christophers, 2015). In a review of the history and definition of financialization, Greta Krippner uses the term to refer to a 'pattern of accumulation in which profit-making occurs increasingly through financial channels 
rather than through trade and commodity production' (Krippner, 2004, p. 14). Financialization includes companies that allocate a proportion of their profits to share buybacks in order to increase share prices. This is a process that also impacts upon the value of executive stock options and corporate pay. In this case, profit is invested to increase the value of a company without investing in process or product innovation that would contribute directly to value creation over a long period. Mazzucato's analysis of value is especially useful in exploring this process. She notes that:

In the 2000s ... the US arm of Ford made more money by selling loans for cars than by selling the cars themselves. Ford sped up the car's transformation from physical product to financial commodity by pioneering the Personal Contract Plan (PCP), which allowed a 'buyer' to pay monthly instalments that only covered the predicted depreciation, and trade up to a new model after two or three years. (Mazzucato, 2018: 162)

The development of PCPs and their adoption by car manufacturers led to another financial innovation. The PCP contracts could be bundled together, securitized, and then resold as a financial product. In essence, financialization involves the action of money on money to produce additional value. The key question is the relationship between this type of financial value and the wealth created by manufacturing goods. Financialization is also applied by manufacturing companies to intellectual property and to trade in innovation (Clark, 2013).

Financialization is found in all sizes of manufacturing companies. Small companies may extract funds to invest in real estate, or other financial assets, as part of a strategy to create assets to underpin owners' pension plans. For larger companies, their GVCs and GPNs cannot be understood without detailed analysis of corporate financialization. This includes depositing money in offshore banks to avoid taxation, and making 'more money than ever before by simply moving money around ... from purely financial activities, such as trading, hedging, tax optimizing, and selling financial services, than they did in the immediate post-World War II period' (Foroohar, 2016: 5). Hedging is commonly applied by manufacturing companies to reduce their exposure to risks related to price volatility and access to raw materials including energy inputs (Mulhall and Bryson, 2013, 2014). For manufacturing companies hedging is a process based around taking purchasing positions to reduce exposure to price movements. This can take two forms: with physical hedging, a supplier agrees to lock in a price for a period with a manufacturer; with financial hedging, the manufacturer uses an intermediary, for example a bank, to agree a locked-in price. The latter type is much more complex as the manufacturer would need to meet the accountancy standards associated with hedging 
activities and derivative instruments. These accountancy standards do not apply to physical hedging. Nevertheless, one advantage of financial hedging is that the price lock-in would be supported by a large financial institution rather than perhaps a much smaller provider of production inputs.

Over the last two decades, perhaps the most productive line of enquiry for research on the global economy, within the critical social sciences, should have focused on the fact that the 'biggest and brightest companies have started to act like banks' (Foroohar, 2016: 4) rather than manufacturing companies. This includes selecting locations for production and assembly plants based on financial rather than operational grounds, including accessing government subsidies.

Second, corporate profitability is often directly or indirectly linked to the exploitation of people, and the environment. This also includes tax avoidance, which is a form of indirect labour exploitation. In this case, a company benefits from taxes invested in education and related services in a national or regional context, but minimizes its own contribution and is thus indirectly subsidized by other taxpayers. These other taxpayers will be companies as well as low-income workers. This is a complex and under-researched issue and is complicated by approaches to financial engineering, including financialization, developed by companies and consultancy firms. Highly profitable companies may be heavily reliant on strategies that include exploitation of people and environmental pollution. A core critical social science research agenda involves identifying how and where manufacturing firms are directly and indirectly engaged in such strategies. This includes designing and fabricating manufactured projects that are impossible to recycle. It also includes products with GPNs configured to maximize profitability, but which exploit people and, at the same time, maximize environmental pollution. All this highlights that further research is required to explore manufacturing as a set of linked multi-scalar processes that engage directly and indirectly with the wider social and physical environments.

\section{The challenge of scale and production processes}

For manufacturing, geography matters: the place, or places, of production matter combined with the places in which product recycling occurs (Lee and Luca, 2019). The question of scale plays a central role in the configuration of manufacturing production processes. A primary research challenge is to develop a much more sophisticated approach to scale. Currently, manufac- 
turing research relies on applying a multi-scalar approach based on allocating production processes to local, regional, national or international/global scales. There are two problems with this approach.

First, at a regional level, regions are defined based on established political, religious or administrative boundaries. These are socially constructed boundaries that often have no meaning for companies. Thus, a focus on understanding the functioning economic geographies of a politically defined region - for example, the West Midlands (UK) - could result in a distorted analysis as economic activity crosses over these socially constructed regional boundaries (Salder and Bryson, 2019). The terms 'international' and 'global' are too often applied to products and companies that operate using a much more restricted geography. One research challenge involves identifying the small number of firms that operate globally rather than internationally. There are no reliable lists of truly global companies. The current lists of global companies use size as a proxy measure, but size does not equate with companies having a global rather than an international footprint (Table 1.1).

Second, scale involves places and flows between places. These flows include people, money, raw materials, components, complete products, services, information, knowledge, environmental pollutants and disease. Connections between places are no longer measured based on geographic distance, but on travel time and, ideally, on carbon footprint. A core challenge for manufacturing research is to develop a much more sophisticated approach to exploring scale. The current approach needs to be problematized, as it has become taken for granted.

The starting point for the problematization of scale is to consider how a local versus a regional company is defined or identified. Do local manufacturing firms exist? Do manufacturing firms exist that operate regionally? The problem is that the definition of local and regional is too often assumed or based on existing socially constructed definitions that are overlaid on to manufacturing companies. These socially constructed definitions are based on established administrative boundaries that, in some contexts, reflect decisions that were made in the far distant past. Thus, the West Midlands is a region defined not on the basis of some objective assessment or appreciation of the area's functioning economic geography. This region is defined based on historic decisions that can be traced back to the emergence of Anglo-Saxon territories around $500 \mathrm{AD}$ and the identification of ten regions by Oliver Cromwell's Protectorate in the 1650s. These types of regions are too often applied to explore firm behaviour and the operation of 'regional' economies. This approach needs to be turned on its head. The alternative approach is based on appreciating 
that scale at the corporate level is socially constructed based on processes of enactment. The implication is that every manufacturing firm will have enacted its own local and regional scales of activities, and these scales may have no relationship with existing administration boundaries. In this account, scale is an experiential process. A research process must be applied to identify a company's local and regional geography, and this may be idiosyncratic. The same approach must be applied to identifying and defining a company's enacted definition of the 'international' or 'global' scale. The national scale is different, as there is a legal definition based on national jurisdictions. Thus, the local, regional, international and global scales are experiential, whilst the national reflects a legal boundary.

The approach to treating scale as a multi-scalar process must be transformed. This approach is too rigid, as it is based on a simplistic account and set of assumptions regarding the complex interrelationships between organizations or individuals, place and space. Multi-scalar processes are in reality experienced and constructed in a much more fluid manner, with constant interactions between different forms of place-based interactions. The relationships between organization and scale are better conceptualized as being based around 'scalar-plasticity' in which there are multiple interlayered geographical relationships between different places that have different characteristics. These relationships involve different types of intensity, including duration, but also some of these inter-place-based interactions are strategic, some emotional and some circumstantial (Salder and Bryson, 2019). This new concept of scalar-plasticity replaces the multi-scalar approach by recognizing that every individual and organization constructs and enacts their own applied or practice definition of scale(s). This makes comparative research much more challenging, as simple unproblematized definitions of local, regional and international/global are replaced by an approach to scale that is framed within the terms set by the individuals and organizations engaging with place and space.

This approach must be applied to international or global processes as they relate to production processes. Every company will enact its own applied definition of international/global through performance and practice. The implication is that there are perhaps as many corporate configurations of the local, regional and global scales as there are companies. There will be a balance between that which is particular to a firm and that which is perhaps more universal, but this requires considerable further research (Sayer, 1982). In this context, it is important to appreciate that there continues to be a considerable Anglophonic bias in manufacturing research. Different cultures will have very different approaches to enacting and defining scale in practice. An important new research agenda involves problematizing scale and developing a more 
practice-orientated approach that will also require methodological innovation. This research agenda must also include comparative research to explore the relationships between culture and scale as a practice-defined process.

There is a danger that research on manufacturing, production networks and scale focuses on the state, firms, and national and global policy. All these are important, but it is also important to remember the role that consumption decisions made by individuals and households play in shaping economic outcomes. Too often consumers are considered to be relatively unimportant as the emphasis is on understanding production processes in isolation from consumption. This is surprising, as supply is considered in isolation from demand. Recently, Clark has noted that it is important 'to consider the local and the household scales which are increasingly sites of policy action - both from the bottom up and the top down' (Clark, 2019: 1179).

There is another complication regarding scale. There is a tendency amongst some social sciences to overemphasize the importance of scale or geography. This is becoming a major constraint on manufacturing research in these disciplinary contexts. In these disciplines, journal editors desk-reject papers that are not positioned within an account of scale. In 1984, Massey developed an important distinction between spatial and aspatial processes. The danger is that overemphasizing spatial processes relegates aspatial processes. Critical economic geography urgently needs to appreciate that aspatial and spatial processes are interlinked in complex ways and that sometimes an analysis must focus on the aspatial aspects of a process. The current overemphasis on spatial processes in economic geography, for example, explains the emphasis placed on clusters and GPNs and the neglect of research on operational management and processes. This is a major problem that can be highlighted via an example.

In February 2021, Mondelēz International announced plans to invest $£ 15$ million (US\$20.5 million) in the company's Bournville site in Birmingham, UK. This site was described as the 'heart and home' of Cadbury (Ferrer, 2021). This investment includes $£ 11$ million to create a production line for Cadbury Dairy Milk chocolate bars (tablets) as part of a strategy to consolidate the majority of tablet production on the Bournville site. This new production line would increase annual capacity by 125 million Cadbury Dairy Milk (CDM) chocolate bars and would come with additional capacity for future growth. The company also planned to invest $£ 4$ million to increase the site's chocolate-making capacity. Since 2014 , the company had invested over $£ 80$ million (US $\$ 109.5$ million) on plant modernization to enhance efficiency. In 2016, production costs at Bournville were three times that of similar factories in Germany and other European markets, but the investments increased production efficiency by 
more than 30 per cent at Bournville since 2014. Bournville is supported by two other UK-based satellite sites. The 2021 planned increase in production capacity involves no additional employment. This is an example in which aspatial and spatial processes are combined. The investment in a new production line reflects a place-based enhancement to operational capacity. This additional capacity could have been located elsewhere. How is this decision explained? In cost terms, there are perhaps locations that would be cheaper and would require reduced investment in technology. Nevertheless, part of this strategy is based on enhancing plant-based productivity by investing in technology rather than hiring people. This is partly about technological substitution for people via operational enhancement.

There is another important aspect to this strategy. Bournville plays an important non-price-based role in this company's competitiveness; CDM was invented in Bournville. There are important place-based associations between this place and the product (Rusten et al., 2007). This site is also the location for Mondelēz International's Global Centre of Excellence for Chocolate Research and Development, including the company's innovation kitchen where all Cadbury products across the globe are invented. There is a paradox here, in that non-cost-based factors may underpin investment and strategic decisions regarding adjustments to the configuration of an existing GPN. In this case, Bournville has important associations for some consumers, but this site also plays an important role in this company's corporate culture. This is a form of corporate emotional attachment to the place that encourages the company to apply a technological substitution strategy to enhance productivity, rather than a spatial strategy based on identifying the cheapest location to produce these products. All this highlights that further research is required to explore the relationships between technological innovation, and related investment strategies, and the spatial configuration of production.

\section{Manufacturing paradoxes and new forms of risk}

Manufacturing is replete with many paradoxes and contrasts, including inertia and rapid change. The word 'manufacture' is a paradox in its own right. This word comes from the Latin manu factum or the action or process of making something by hand. This term was applied to the making of products by physical labour, or mechanical power, in the seventeenth century (Bryson and Rusten, 2011: 164). Manufacturing includes highly automated systems as well as labour-intensive production processes. It includes, for example, synthetic fibres that are created chemically and woven using highly automated 
machines, with integrated drive operations facilitated by industrial network architecture to facilitate the flow of data around a plant and international business (Bryson and Ronayne, 2014). Nevertheless, it also includes Harris Tweed ${ }^{\circledR}$, which is the only fabric in the world governed by its own Act of Parliament, the 1993 Harris Tweed Act. Harris Tweed is 'hand-woven by the islanders at their homes in the Outer Hebrides, finished in the Outer Hebrides, and made from pure virgin wool dyed and spun in the Outer Hebrides' (Platman, 2011: 24).

One of the paradoxes of manufacturing is related to the emergence of new forms of risk. Both Beck (1992) and Giddens (1998) have explored the emergence of a new risk society. Manufacturing is associated with new technological solutions that are intended to transform everyday living, reducing risk. Nevertheless, the strange paradox here is that 'risk might in fact be increasing due to technology, science and industrialism rather than being abated by scientific and technological progress' (Jarvis, 2007: 23). There are many explanations for this paradox.

On the one hand, everyday living is supported by complex assemblages of manufactured products. Any component breakdown may result in widespread systemic failure. A 'cyber-energy-production plexus' has formed around multiple connections between telecommunication, energy and production networks (Bryson et al., 2021). Across manufacturing, industrial control systems (ICSs) have been developed that integrate hardware with software through network connectivity. ICSs underpin critical infrastructure within production systems. Historically, production equipment was isolated or air-gapped from the outside world. The cyber-energy-production plexus includes directly or indirectly linking ICS components to the internet and these expose core operational systems to cyberattacks. An excellent example is the extensive cybersecurity attack on Norsk Hydro, one of the largest producers of aluminium in the world, with smelting plants, factories and offices in 40 countries. On 19 March 2019, a classic ransomware cyberattack affected information technology (IT) systems in most business areas. The company's worldwide IT network went down, and the company had to switch its ICS from automated to manual. The company did not pay a ransom, but the cyberattack cost at least $£ 300$ million Norwegian kroner (£25.6 million). Every local factory manager was tasked with maintaining customer orders, and the company instigated an incident representation response plan that included a temporary website. Microsoft employees and representatives from cybersecurity firms were flown in to assist the company. Full recovery was estimated to take months (Beaumont, 2019). Cyberattacks have become one of the primary risks facing all ICSs that are linked to the internet. 
On the other hand, the ongoing development of the cyber-energy-production plexus is associated with the creation of tightly coupled systems. Charles Perrow (1984) made important contributions to understanding the emergence of new forms of risk in tightly coupled systems. He identified two factors that enhance system susceptibility to risk. First, risk emerges in the ways in which different parts of a system interact with one another. Some systems are linear, making any failure immediately obvious; whilst other systems are much more complex, with different parts of the system interacting with one another in unexpected ways. Much that occurs in complex systems is hidden. The second factor in Perrow's theory is based on how much slack exists in a system. This concept of slack comes from the engineering literature on tight coupling or system optimization. In this account of engineering systems, tight coupling is associated with limited slack, or buffering, existing between different parts of the system. The opposite of tight coupling is loose coupling, in which slack exists in a system, with the result being that any failure of one part of a system can be covered by the slack that exists elsewhere. Loose coupling enables a system to respond to shock, as sufficient additional capacity, including alternative routeways, may be available during times of crisis. The danger is that GPNs which are configured around cost control and profitability also tend to be tightly coupled networks in which decision-making has focused on system optimization rather than system resilience.

Another manufacturing paradox is the relationship between a focus on enhancing productivity in production processes and risk. All production-orientated theory must include a focus on understanding the drivers behind the race to enhance productivity, and the perverse consequences of this process. Productivity is a measure of the ratio of inputs to outputs in a production process. Some manufacturing firms are fixated with a concern to enhance productivity. This includes identifying tasks to relocate to low-cost labour locations, combined with substituting labour with machines. Productivity can be a measure of team or plant performance as well as being applied nationally as part of a comparative assessment of national productivity differentials (McCann, 2009).

In 1994, Paul Krugman proclaimed that: 'Productivity isn't everything, but in the long run it is almost everything. A country's ability to improve its standard of living over time depends almost entirely on its ability to raise its output per worker' (Krugman, 1994: 13). This quotation has become a cliché to support debates on the importance of productivity in national and regional economies (McCann, 2009: 280). Krugman's statement is both correct and misleading and: 'should be rewritten: "Invention and innovation isn't everything, but in the long run it is almost everything in facilitating productivity improvements". 
The problem is one of causality: productivity improvements are an output of invention and innovation' (Bryson et al., 2020: 35-36).

Nevertheless, the application of invention and innovation to manufacturing companies in order to increase productivity involves system optimization, and this includes tight coupling; tight coupling enhances exposure to risk and reduces corporate resilience. A major challenge facing all manufacturing companies is the need to balance system optimization against risk to ensure that sufficient loose coupling or organizational slack exists (Cyert and Marsh, 2001). Identifying risk and developing approaches to ameliorating societal risks should be at the centre of all socially responsible social science, and it is to this topic that we now turn our attention.

\section{Manufacturing research and socially responsible social science}

The term 'critical human geography' emerged in the mid-1990s as part of a debate in Anglophonic geography that engaged with a broader debate on critical social science. Critical human geography represents 'a diverse set of ideas and practices linked by a shared commitment to a broadly conceived emancipatory politics, progressive social change, and the use of a range of critical socio-geographic theories' (Berg, 2010: 617). At one level, this is a purely academic project with analysis placed in the context of a call for progressive social change; but at another level, this is a call for applied and action-oriented research that is intended to make a difference (Martin, 1999, 2001; Massey, 2000; Pollard et al., 2000). The challenge for critical human geography is to develop a dialogue between geographical research and ongoing debates on the ethical challenges related to socially responsible science. The literature on socially responsible science highlights that 'scientists have a responsibility to address the social implications of their research' (Resnik and Elliott, 2016: 31). This is a complex process, since 'acknowledging one's social responsibilities as a scientist is only the beginning of dealing with the value implications of one's work, since responsibility requires one to address the moral, political, social, and policy issues at stake' (Resnik and Elliott, 2016: 32). The definition of social responsibility is context-specific as every topic will have a different set of related social implications. This could include engaging with the 17 Sustainable Development Goals (SDGs) identified by the United Nations in 2015 (UN General Assembly, 2015). 
The manufacturing research agenda must be positioned within a debate on socially responsible research. There is a tension here. On the one hand, all researchers are consumers; every time we consume, we support employment, create employment and destroy jobs, whilst also supporting and contributing to all types of environmental pollution. Social scientists should engage in socially responsible consumption. Defining this represents a critical research agenda, and enacting this as everyday behaviour is challenging. On the other hand, deciding not to consume is impossible, but selective and socially responsible consumption is perfectly possible. An avenue for research revolves around approaches to balancing the tensions between consumption and social responsibility.

For the academic this is about recognizing 'the value implications of one's research [as] an important first step towards exercising social responsibility' (Resnik and Elliott, 2016: 37). Ignoring this is not an option, as this would be to act irresponsibility, 'because behaving responsibly requires one to deal with the implications of one's conduct' (Resnik and Elliott, 2016: 37). For those involved in manufacturing research, social responsibility involves identifying the perverse consequences of manufacturing and then working to address these consequences. This includes identifying products and GPNs that incorporate any form of labour exploitation, including modern-day slavery. This includes labour exploitation that sits across a GPN, including raw material inputs and those involved in logistics and recycling. It also includes identifying those parts of a GPN that are carbon-intensive or which contribute to environmental pollution.

It used to be the case that academics conducted rigorous and robust research and that social responsibility was passed onto policymakers, politicians, journalists and the public, whose roles included dealing with the consequences of new knowledge. This is no longer the case. It has become increasingly unacceptable for academics to adopt a value-free approach, but instead, where appropriate, research agendas must include a concern with social responsibility. This is an important point for journal editors to consider. Editors and reviewers should be asked to assess a paper based on academic rigour combined with social responsibility. Authors should be encouraged, where appropriate, to provide a social responsibility statement that, for example, aligns their paper's contribution to the SDGs. Such a statement would highlight the wider societal implications of the research and would include an impact statement. All social science journals should clearly acknowledge the critical importance 
of adopting and enacting effective approaches to supporting and encouraging socially responsible social science. This includes three dimensions:

1. Problem selection.

2. Data sharing and open access publication.

3. Public engagement.

We will consider each of these in turn.

First, problem selection requires careful reflection regarding the comparative importance of a research challenge. This includes an assessment of the number of people and non-humans who would be impacted upon by a process that is selected as the object of research. Thus, some problems challenge the life chances of many millions of people, and then there are other problems that impact on one or two individuals or non-humans. Socially responsible social science requires a justification for focusing time and resources on one research challenge compared to another.

Second, publication must be considered carefully. Too frequently, the place of publication is based on citations, journal impact scores or journal rankings. A socially responsible publication strategy would include due consideration regarding the wider societal relevance of a publication. Across the social sciences, an overemphasis on the theoretical contribution that a paper makes has emerged. Thus, for many journals the decision to publish a paper is not based on societal relevance combined with social responsibility, but on the contribution a paper makes to academic theory. There are perverse consequences of this approach. It means that papers might be rejected that identify pathways to create better societal outcomes, on the grounds that they do not make a theoretical contribution. A key debate that is urgently required is the tension between theoretical versus socially responsible research contributions.

Third, socially responsible social science involves more than publishing for career advancement. An important question concerns the assessment of the quality of a publication. Do we use proxy measures, including the publisher's reputation or the impact factor or ranking of a journal? To Kennedy (1999: 192), 'in the end the judgments of peers - often after a substantial lapse of time - will yield the most reliable verdict'. Kennedy was writing in 1999, and times have moved on. The judgement of peers would suggest that research and publication is targeted at other academics rather than the wider society. The final judgement regarding the quality of a paper should be based on wider societal relevance. This includes authors engaging in public engagement activities to ensure that the implications of a research project are addressed. This includes 
direct and indirect public engagement activities. Indirect activities include incorporating new knowledge into university courses; teaching becomes an important element in socially responsible social science. Direct activities include press releases, social media, blogs, providing expert testimony, publicly advocating for change via media interviews and public speeches, and direct intervention. Direct intervention includes establishing not-for-profit companies to address private and public sector failure, and whistleblowing regarding unethical and irresponsible activities.

\section{Conclusions}

This book is intended to contribute towards identifying a research agenda for manufacturing. It is important that all involved in manufacturing research periodically stand back from their everyday practices and reflect on what they are trying to achieve. This period of reflection should also consider the social relevance of their research and teaching contributions.

This raises the question of what contribution social science should make to society. This might be defined in the terms of critical commentary combined with a socially responsible research agenda that is intended to enhance societal outcomes. For manufacturing-orientated research this raises some interesting questions:

1. Is the objective enhanced understanding of manufacturing processes as an end in itself to inform a predominantly academically orientated discussion?

2. Is the objective focused on research that is intended to improve company performance?

3. Is the objective focused on labour and the conditions of employment with a focus on trying to produce better outcomes for people?

4. Is the emphasis on research that is intended to reduce negative environmental consequences of manufacturing processes including recycling and waste?

5. Is the objective about identifying different ways in which policy can shape outcomes?

6. Is the objective to develop understanding to inform teaching on the understanding that better-informed graduates will make better decisions?

These questions are critical, but too frequently ignored. There is a real danger that an overemphasis on academically focused research, as well as theoretically focused research, undermines the perceived contribution that social science 
makes to society. There must be some perceived and actual broader societal contribution.

The chapters in this book set out a series of thematic, theoretical and methodological contributions that inform the development of manufacturing research agendas. In Chapter 2, Chloe Billing and John Bryson explore the emergence of new industries as a process that challenges existing conventions. This chapter sets out a legitimacy-building framework for exploring emerging industries. This approach to emerging industries provides the backdrop for Jennifer Johns's (Chapter 3) analysis of a research agenda framed within a discussion of additive manufacturing including three-dimensional (3D) printing. This chapter identifies four key research directions for research on additive manufacturing. Developments in production technologies underpin some of the aspects of a new research agenda for research on the automotive industry that is explored by Godfrey Yeung in Chapter 4. In this analysis, he identifies disruptive megatrends that are creating new automotive companies and even new automotive subsectors. This includes artificial intelligence (AI) and autonomous driving that is blurring the boundaries between software and hardware. Part of the context of this chapter is highlighting the need for further research that will explore resilience and supply chain management.

Emerging industries and disruptive innovation are linked to alternations in labour markets and in the skills that support manufacturing. In Chapter 5, Anne Green and Abigail Taylor explore the changing skills and policy requirements for manufacturing. This includes the challenge of replacement demand in local labour markets linked to skills gaps and skills underutilization. This discussion of policy provides an entry point into Chapter 6 by William Graves and Harrison Campbell, Jr. This chapter focuses on the automotive industry and the impacts that policy has had on reshaping the geography of the American automotive industry. This is positioned within an account of the evolution of clustering strategies and highlights that there is an important research agenda that focuses on policy, place and manufacturing. This requires the application of a holistic approach to explore the wider impacts of policy on companies, place, labour markets and the wider society.

The analysis then shifts to focus on SMEs and manufacturing. Intermediaries play an important role in regional and national economies. In Chapter 7, Ronald Kalafsky and Douglas Gress focus on one type of intermediary: trade fairs. This chapter highlights the ways in which research on trade fairs is one entry point to explore the export dynamics and learning networks of SME manufacturers. Everyday living is supported by an ever-increasing array of devices that rely on electronics. The production of these devices is based on 
a complex and evolving set of GPNs. These GPNs are supported by SMEs, and trade shows are important intermediary spaces that facilitate the development of new GPNs and products. In Chapter 8, David Chan and Chun Yang explore the transformation of Asian electronics production networks as a pathway to identifying new research agendas on manufacturing in general and the electronics industry in particular. Production is underpinned by production management and operations and supply chain management. Chapter 9, by Donato Masi and Janet Godsell, explores approaches to undertaking research on operations and supply chain management, with an emphasis on rigour and relevance. Rigour comes from embedding empirical research within a theoretical framework, but research should also be relevant, and this includes encouraging alterations in company behaviour.

Research that is rigorous and relevant must be underpinned by an appropriate research design and related methods. The focus of Chapter 10 by John Bryson et al. is on corporate interviewing as a methodological tool, but the emphasis is on accessing corporate elites. This chapter develops a framework for accessing corporate elites that draws upon the experiences of four $\mathrm{PhD}$ students who completed research on manufacturing companies. The framework includes an analysis of the role social media and networking tools may play in accessing corporate elites.

The final chapter of this edited collection, Chapter 11 by John Bryson, outlines and develops an approach to reading businesses to inform practice, research and policy. This approach includes identifying 28 key questions that should underpin any attempt to read a business. This reading business approach is then applied to develop a research agenda for manufacturing research. This includes further research on value, operations, care and responsibility, including diversity, risk and uncertainty, products and scale, including the development and application of the scalar-plasticity approach to the scale question. This is positioned within a broader argument regarding the emergence of a new epoch in the ongoing evolution of capitalism. We have entered the period of Jenga Capitalism, in which system convergence, combined within increased global connectivity, produces domino effects that ripple across the globe, enhancing inequalities, and disrupting global production networks and national economies.

Currently, humanity faces five critical challenges:

1. Climate change and the race to decarbonize production and consumption, including minimizing the environmental and societal impacts of supply chains and production/consumption processes. 
2. Inclusive prosperity that is truly inclusive and sustainable.

3. Risks related to system convergence and optimization including cybersecurity.

4. Risks related to biological hazards and pandemics.

5. The impacts of developments in artificial intelligence (AI) and robotics on manufacturing, employment, consumption, governance and lifestyles.

These are five cross-cutting themes that will result in the emergence of new industries, technologies, production processes and lifestyles. Life as we know it will change radically over the next decade as production processes and lifestyles increasingly decarbonize. There will also be important implications for labour markets and skills. All these five themes will play an important role in the manufacturing research agendas that will emerge over the next decade.

\section{References}

BBC (2021), 'BP staff set to work from home two day a week', BBC News, accessed 8 March 2021, available at https://www.bbc.co.uk/news/business-56319623.

Beaumont, K. (2019), 'How Lockergoga took down Hydro - ransomware used in targeted attacks aimed at big business', accessed 10 February 2021, available at https://doublepulsar.com/how-lockergoga-took-down-hydro-ransomware-used-in -targeted-attacks-aimed-at-big-business-c666551f5880.

Beck, U. (1992), Risk Society: Towards a New Modernity, London: SAGE.

Berg, L. (2010), 'Critical human geography', in Warf, B. (ed.), Encyclopedia of Geography, London: SAGE Publications, pp. 617-621.

Boz, Z., Korhonen, V. and Koelsch C.S. (2020), 'Consumer considerations for the implementation of sustainable packaging: a review', Sustainability, 12(6): 2192. https://doi.org/10.3390/su12062192.

Bryson, J.R., Andres, L., Ersoy, A. and Reardon, L. (2021), 'A year into the pandemic: shifts, improvisations and impacts for people, place and policy', in Bryson, J.R., Andres, L., Ersoy, A. and Reardon, L. (eds), Living with Pandemics: Places, People and Policy, Cheltenham, UK and Northampton, MA, USA: Edward Elgar Publishing, pp. 2-34.

Bryson, J.R., Mulhall, R.A., Song, M., Loo, B., Dawson, R.J. and Rogers, C.D.F. (2018), 'Alternative-substitute business models and the provision of local infrastructure: alterity as a solution to financialization and public-sector failure', Geoforum, 95: $25-34$.

Bryson, J.R. and Ronayne, M. (2014), 'Manufacturing carpets and technical textiles: routines, resources, capabilities, adaptation, innovation and the evolution of the British textile industry', Cambridge Journal of Regions, Economy and Society, 7(3): 471-488.

Bryson, J.R. and Rusten, G. (2011), Design Economic and the Changing World Economy, London: Routledge. 
Bryson J.R., Sundbo, J., Fuglsang, L. and Daniels, P. (2020), Service Management: Theory and Practice, London: Palgrave Macmillan.

Bryson J.R. and Taylor, M. (2010), 'Mutual dependency, diversity and alterity in production: cooperatives, group contracting and factories', in Fuller D., Jonas A.E. and Lee R. (eds), Interrogating Alterity, Farnham: Ashgate, pp. 75-94.

Bryson, J.R. and Vanchan, V. (2020), 'COVID-19 and alternative conceptualisations of value and risk in GPN research', Tijds. voor econ. en Soc. Geog., 111: 530-542.

Christophers, B. (2015), 'The limits to financialization', Dialogues in Human Geography, 5(2): 183-200.

Clark, J. (2013), Working Regions: Reconnecting Innovation and Production in the Knowledge Economy, London: Routledge.

Clark, J. (2019), 'Remodeling capitalism: a return to scale', Environment and Planning A: Economy and Space, 51(5): 1178-1180

Cyert, R.M. and Marsh, J.G. (2001), A Behavioural Theory of the Firm, Oxford: Blackwell.

Dangelico, R.M. and Pujari, D. (2010), 'Mainstreaming green product innovation: why and how companies integrate environmental sustainability', Journal of Business Ethics, 95: 471-486.

Daniels, P.W. and Bryson, J.R. (2002), 'Manufacturing services and servicing manufacturing: knowledge-based cities and changing forms of production', Urban Studies, 39(5-6): 977-991.

Dicken, P. and Thrift, N. (1992), 'The organization of production and the production of organization: why business enterprises matter in the study of geographical industrialization', Transactions of the Institute of British Geographers, New Series 17: 279.

Doi, N. and Cowling, M. (1998), 'The evolution of firm size and employment share distribution in Japan and UK manufacturing: a study of small business presence', Small Business Economics, 10: 283-292.

Fernández-Esquinas, M., van Oostrom, M. and Pinto, H. (2017), 'Key issues on innovation, culture and institutions: implications for SMEs and micro firms', European Planning Studies, 25(11): 1897-1190.

Ferrer, B. (2021), 'Cadbury to return to Bournville with US\$20.5M investment in Dairy Milk tablets production', Food Ingredients 1st, accessed 17 February 2021, available at https://www.foodingredientsfirst.com/news/cadbury-to-return-to-bournville -with-us205m-investment-in-dairy-milk-tablets-production.html.

Foroohar, R. (2016), Makers and Takers: The Rise of Finance and the Fall of American Business, New York: Crown Business.

Fortune (2020), Global 500, accessed 16 February 2021, available at https://fortune .com/global500/2020/search/.

Gallemore, C., Nielsen, K.R. and Jespersen, K. (2019), 'The uneven geography of crowdfunding success: spatial capital on Indiegogo', Environment and Planning A: Economy and Space, 51(6): 1389-1406.

Ge, C., Zhang, S.-G. and Wang, B. (2020), 'Modeling the joint distribution of firm size and firm age based on grouped data', PLOS ONE, 15(7): e0235282. https://doi.org/10 .1371/journal.pone.0235282.

Giddens, A. (1998), The Third Way: The Renewal of Social Democracy, Cambridge: Polity Press.

Goldstein, B. and Newell, J.P. (2019), 'Why academics should study the supply chains of individual corporations', J. Ind. Ecol., 23(6): 1316-1327, 10.1111/jiec.12932.

ILO (2017), Global estimates of Modern Slavery, ILO: Geneva. 
IMO (2020), Reduction of GHG Emissions from Ships: Fourth IMO GHG Study 2020, London: IMO.

Jarvis, D.S.L. (2007), 'Risk, globalisation and the state: a critical appraisal of Ulrich Beck and the world risk society thesis', Global Society, 21(1): 23-46.

Kennedy, D. (1999), Academic Duty, Cambridge, MA: Harvard University Press.

Krippner, G. (2004), 'What is financialization', mimeo, Department of Sociology, UCLA.

Krugman, P. (1994), The Age of Diminishing Expectations, Boston, MA: MIT Press.

Lee, N. and Luca, D. (2019), 'The big-city bias in access to finance: evidence from firm perceptions in almost 100 countries', Journal of Economic Geography, 19(1): 199-224.

Martin, R.L. (1999), "The "new economic geography": challenge or irrelevance?', Transactions, Institute of British Geographers, 24: 387-391.

Martin R. (2001), 'Geography and public policy: the case of the missing agenda', Progress in Human Geography, 25(2): 189-210.

Maskell, P. (2001), 'The firm in economic geography', Economic Geography, 77(4): 329-344.

Massey, D. (1984), Spatial Division of Labour: Social Structures and the Geography of Production, London: Palgrave.

Massey, D. (2000), 'Practising political relevance', Transactions, Institute of British Geographers, 24: 131-134.

Mazzucato, M. (2018), The Value of Everything, London: Allen Lane.

McCann, P. (2009), 'Economic geography, globalisation and New Zealand's productivity paradox', New Zealand Economic Paper, 43(3): 279-314.

Mulhall, R. and Bryson, J.R. (2013), 'The energy hot potato and governance of value chains: power, risk and organizational adjustment in intermediate manufacturing firms', Economic Geography, 89(4): 395-419.

Mulhall, R.A. and Bryson, J.R. (2014), 'Energy price risk and the sustainability of demand side supply chains', Applied Energy, 123: 327-334.

NCEO (2020), 'The Employee Ownership 100: America's largest majority employee-owned companies', National Center for Employee Ownership, accessed 16 February 2021, available at https://www.nceo.org/articles/employee-ownership -100 .

Nguyen, Anh Thu, Parker, L., Brennan, L. and Lockrey, S. (2020), 'A consumer definition of eco-friendly packaging', Journal of Cleaner Production, 252: 119792.

Nooteboom, B. (2000), Learning and Innovation in Organisations and Economies, Oxford: Oxford University Press.

Peattie, K. and Crane, A. (2005), 'Green marketing: legend, myth, farce or prophesy?', Qualitative Market Research, 8(4): 357-370.

Peck, J. (2019), Offshore: Exploring the Worlds of Global Outsourcing, Oxford: Oxford University Press.

Perrow, Charles (1984), Normal Accidents: Living With High Risk Technologies, Princeton, NJ: Princeton University Press.

Platman, L. (2011), Harris Tweed: From Land to Street, London: Francis Lincoln.

Pollard, J., Henry, N., Bryson, J. and Daniels, P. (2000), 'Shades of grey? Geographers and policy', Transactions, Institute of British Geographers, 24: 243-248.

Resnik, D.B. and Elliott, K.C. (2016), 'The ethical challenges of socially responsible science', Accountability in Research, 23(1): 31-46. 
Rusten, G., Bryson, J.R. and Aarflot, U. (2007), 'Places through products and products through places: industrial design and spatial symbols as sources of competitiveness', Norsk Geografisk Tidsskrift, 61(3): 133-144.

Salder, J. and Bryson J.R. (2019), 'Placing entrepreneurship and firming small town economies: manufacturing firms, adaptive embeddedness, survival and linked enterprise structures', Entrepreneurship and Regional Development, 31(9-10): 806-825.

Sauser, W.I (2009), 'Sustaining employee owned companies: seven recommendations', Journal of Business Ethics, 84: 151-164

Sayer, A. (1982), 'Explanation in economic geography: abstraction versus generalization', Progress in Human Geography, 6(1): 68-88.

Skoda, E. (2019), 'The monomaterials challenge', Packaging Europe, accessed 16 February 2021, available at https://packagingeurope.com/the-monomaterials -challenge/.

Taylor, M. (2006), 'Fragments and gaps: exploring the theory of the firm', in Taylor, M. and Oinas, P. (eds), Understanding the Firm: Spatial and Organizational Dimensions, Oxford: Oxford University Press, pp. 3-31.

Taylor, M. and Asheim, B. (2001), 'The concept of the firm in economic geography', Economic Geography, 77(4): 315-328.

Taylor, M. and Bryson, J.R. (2006), 'Guns, firms and contracts: the evolution of gun-making in Birmingham', in Taylor, M. and Oinas, P. (eds), Understanding the Firm: Spatial and Organizational Dimensions, Oxford: Oxford University Press, pp. 61-84.

UN General Assembly (2015), Transforming our World: The 2030 Agenda for Sustainable Development, A/RES/70/1, accessed 13 March 2021, available at: https:// www.refworld.org/docid/57b6e3e44.html.

Urry, J. (2014), Offshoring, Cambridge: Polity.

Vanchan, V., Mulhall, R. and Bryson, J. (2018), 'Repatriation or reshoring of manufacturing to the US and UK: dynamics and global production networks or from here to there and back again', Growth and Change, 49: 97-121.

Wang, Q. (2019), 'Gender, race/ethnicity, and entrepreneurship: women entrepreneurs in a US south city', International Journal of Entrepreneurial Behavior and Research, 25(8): 1766-1785. 